DOI: https://doi.org/10.36477/tourismhospcee-1-5

УДК 368.1:1:338.48

Копилюк О. I.

доктор економічних наук, професор, завідувач кафедри фінансово-економічної безпеки та банківського бізнесу Львівського торговельно-економічного університету ORCID: https://orcid.org/0000-0002-0977-1309

Kopylyuk Oksana

Lviv University of Trade and Economics

\title{
ОСОБЛИВОСТІ ФОРМУВАННЯ СИСТЕМИ СТРАХОВОГО ЗАХИСТУ В ТУРИСТИЧНІЙ ДІЯЛЬНОСТІ
}

\section{FEATURES OF FORMATION OF INSURANCE PROTECTION SYSTEM IN TOURIST ACTIVITY}

\begin{abstract}
Запропоновано авторський підхід до трактування суті поняття «страхування у туризмі». Доведено, щзо иче особливий вид ичивільно-правових відносин, регламентованих договором страхування, пов'язаних із наданням страхового захисту при настанні страхових випадків в умовах невизначеності та впливу ризиків, які супроводжують діяльність суб'єктів внутрішнього та зовнішнього туризму. Автором обгрунтовано необхідність формування системи страхового захисту в туристичній діяльності, яку запропоновано розглядати як сукупність взаємопов'язаних елементів, які тісно взаємодіють між собою, визначаються залежно від форми страхування й страхового обслуговування, ймовірності настання страхових випадків, необхідності здійснення страхового відшкодування для забезпечення захисту й безпеки у туризмі. Відзначено, щьо найбільш характерними видами ризиків у туристичній діяльності є фінансові, організаційні та операційні.
\end{abstract}

Ключові слова: туризм, страховик, страхувальник, система страхового захисту, страхові ризики.

Предложен авторский подход к трактовке сущности понятия «страхование в туризме». Доказано, что это особый вид гражданско-правовых отношений, регламентированных договором страхования, связанных с предоставлением страховой зашиты при наступлении страховых случаев в условиях неопределенности и влияния рисков, сопровождающих деятельность субъектов внутреннего и внешнего туризма. Автором обоснована необходимость формирования системы страховой зашиты в туристической деятельности, которую предложено рассматривать как совокупность взаимосвязанных элементов, которые тесно взаимодействуют между собой, определяются в зависимости от формы страхования и страхового обслуживания, вероятности наступления страховых случаев, необходимости осуществления страхового возмешуения для обеспечения защиты и безопасности в туризме. Отмечено, что наиболее характерными видами рисков в туристической деятельности являются финансовые, организационные и операционные.

Ключевые слова: туризм, страховщик, страхователь, система страховой защиты, страховые риски.

The author proposed the approach to the interpretation of the essence of the concept of "insurance in tourism", which based on a review of existing scientific developments. On the point of author, it's the special type of civil law relations regulated by the insurance contract, related to the provision of insurance protection in case of insured events in conditions of uncertainty and the impact of risks that accompany the activities of domestic and foreign tourism. The relationship between the insurer and the insured within the framework of concluded agreements regulates the payment of insurance amounts, assessment of insurance risks, application of conditional and unconditional deductible, insurance indemnities, etc. and are systemic in nature. The author substantiates the need to form a system of insurance protection in tourism. In particular, such a system should provide legal registration of compulsory, medical, accident and other types of tourist insurance, finding ways to minimize the impact of negative risks and threats and the formation of personal and collective security of tourists, expanding services to insure medical expenses of tourists in a pandemic COVID-19, need for accident insurance. Improved insurance protection system in tourism, which is a set of interrelated elements that interact closely with each other, determined depending on the form of insurance and insurance services, the probability of insured events, the need for insurance to ensure protection and safety in tourism. It is noted that in the tourist market insurance services are provided in compensation and service (assistance) forms. It is proved that the systematization of risks in tourism should be carried out according to the criteria of their division into the risks of the tourist and the risks of tourist organizations. he most typical types of risks in tourism are financial, organizational and operational. Risks in tourism require clear identification, measurement, evaluation and insurance. Insurance is recognized as one of the effective risk management strategies aimed at minimizing them.

Keywords: tourism, insurer, insured, insurance protection system, insurance risks. 
Постановка проблеми. Екзистенційні виклики та загрози, такі як пандемія COVID-19 суттєво вплинули на скорочення масштабів як внутрішнього, так і зовнішнього туризму, а відповідно і на обсяги реалізації страховими компаніями послуг страхування. Згідно аналітичних даних (WITS) Світового банку сектор подорожей та туризму зазнав у 2019 р. збитків у розмірі 4,5 трлн. дол. США, які досягнули у 2020 p. 4,7 трлн. дол. США, а частка даної галузі у ВВП зменшилася на 49,1\% у порівнянні з 2019 р., при загальному зменшенні світового ВВП на 3,7 \% у 2020 р. [1]. У даній ситуації такі обов'язкові види страхування у туризмі як медичне та від нещасних випадків зумовили потребу запровадження комплексного страхування подорожуючих, включаючи особистий та майновий захист і стали необхідною вимогою під час закордонних поїздок. Дослідження особливостей надання страхових послуг у туризмі, розвиток новітніх продуктів в умовах збільшення їх кількості та ймовірності настання страхових випадків, актуалізували необхідність використання системного підходу до страхового захисту суб'єктів туристичної діяльності.

Аналіз останніх досліджень і публікацій. Проблемам страхування у туристичній діяльності та методам надання страхового захисту присвячені наукові праці багатьох вітчизняних та зарубіжних учених, зокрема таких як: Д. Абрамітова, Р. Адамова, Б. Вихристенко, М. Д'яконідзе, Д-М. Йордан, Є. Козловський, М. Рібун, Н. Опанасюк, С. Сава, П. Талескі та інших.

Виділення невирішених раніше частин загальної проблеми, котрим присвячусться означена стаття. Проте невирішеними залишаються питання обгрунтування елементів системи страхового захисту в туристичній діяльності у разі настання страхових випадків, а саме: медичних витрат, нещасних випадків, цивільної відповідальності, страхування багажу та фінансових ризиків, пов'язаних із відміною подорожі.

Формулювання цілей статті. Метою статті $€$ обгрунтування особливостей та складових елементів системи страхового захисту в туристичній діяльності.

Виклад основного матеріалу дослідження. Усі суб'єкти туристичної діяльності пов'язані із наданням туристичних послуг відносяться до сфери адміністративного та допоміжного обслуговування. Зокрема, М. Ю. Барна, Б. Б. Семак зазначають, що в умовах сьогодення туристична індустрія виробляє, продає та споживає послуги, пов'язані $з$ організацією поїздок для людей, які тимчасово перебувають поза місцем постійного проживання та не здійснюють оплачувану діяльність за місцем перебування [2, с. 34].

Відповідно до різноманітності глобальних та пандемічних умов, виникли нові, орієнтовані на сучасні виклики, послуги страхування подорожей і стали невід'ємним атрибутом при розробці туристичних пакетів. Зростання ризиків і загроз, які негативно впливають на усіх суб'єктів туристичної діяльності, зумовило необхідність подальшого розвитку обов'язкового та добровільного страхування.

Варто зазначити відсутність усталених підходів у розумінні ролі та значення страхування у сфері туризму. Зокрема, згідно підходу М. В. Рібун страхування у туризмі можна розглядати як систему фінансово-економічних відносин між страховими компаніями, суб'єктами туристичної діяльності та туристами 3 приводу задоволення інтересів i потреб кожного з них [3, с. 276]. Автор акцентує на важливості системного підходу в організації надання послуг страхування у туризмі.

Згідно досліджень Д. Р. Абрамітової страхування у туризмі - система взаємозв'язків між страховою компанією і туристом по забезпеченню захисту життя, здоров'я та майнових інтересів громадян під час туристичної подорожі [4, с. 134]. Дискусійним положенням у даному твердженні $€$ те, що наголошується виключно на особистому страхуванні, яке є обов'язковим, обмежується у певній мірі сфера надання страхових послуг й не враховуються усі можливі страхові випадки.

Більш широке визначення у даному контексті пропонує Є. В. Козловський і вважає, що це система відносин між страховою компанією i туристом із захисту його життя, здоров'я, майнових інтересів при настанні страхових випадків. Страхування здійснюється також господарюючими суб'єктами, які страхують своє майно, транспортні, засоби, страхові ризики [5, с. 70].

Майя Діаконідзе вважає, що страхування туризму - один із найважливіших елементів планування подорожей, який захищає туристів від певних фінансових ризиків та втрат, які можуть виникнути під час їх здійснення [1].

Р. А. Адамова наголошує, що це сфера страхування, де основним суб'єктом виступає громадянин країни під час відпочинку [6, с. 70], а також наголошує, що особисте страхування туриста відноситься до ризикових видів страхування.

Б. Вихристенко та Н. Опанасюк розкриваючи правові засади страхування в туризмі відзначають, що це система правовідносин між туристами, суб'єктами туристичної діяльності і страховими компаніями щодо захисту життя туристів, їх здоров'я та майнових інтересів у разі настання певних подій (страхових випадків), яка здійснюється в межах чинного законодавства [7, с. 20].

Вважаємо, що страхування у туризмі - це особливий вид цивільно-правових відносин, регламентованих договором страхування, пов'язаних із наданням страхового захисту у разі настання страхових випадків в умовах невизначеності та впливу 
ризиків, які супроводжують діяльність суб'єктів внутрішнього та зовнішнього туризму. Взаємовідносини між страховиком та страхувальником в рамках укладених договорів регламентують виплату страхових сум, оцінку страхових ризиків, застосування умовної та безумовної франшизи, страхові відшкодування тощо та носять системний характер.

3 позицій безпеки страхового бізнесу така система повинна охоплювати сукупність взаємопов'язаних елементів, які формують основну та забезпечуючу підсистеми, характеризуються відповідним станом захищеності від ризиків та загроз, функціонально поєднані між собою та володіють достатнім ресурсним потенціалом для максимально ефективної реалізації страхових продуктів та послуг [8, с. 298].

В умовах сьогодення необхідність формування системи страхового захисту в туристичній діяльності обумовлена:

1) нормативно-правовим оформленням обов'язкового, медичного, від нещасних випадків й інших видів страхування туристів;

2) пошуком шляхів мінімізації впливу негативних ризиків і загроз, формуванням особистісної та колективної безпеки туристів шляхом укладання угод із страховиками;

3) розширенням послуг із страхування медичних витрат туристів в умовах пандемії COVID-19 (швидка невідкладна допомога, стаціонарне лікування, оплата вартості експрес-тестування, транспортування та медичний супровід застрахованої особи до місця постійного проживання, репатріація, послуги з поховання тощо);

4) потребою страхування від нещасних випадків під час зовнішнього та внутрішнього туризму;

5) побажанням туриста забезпечити уникнення ризику пошкодження багажу, його крадіжки, втрати тощо;

6) мінімізацією фінансових ризиків, пов'язаних із відміною, перериванням подорожей, неможливістю їі здійснення із різних причин.

На нашу думку, система страхового захисту у туристичній діяльності $є$ сукупністю взаємопов'язаних елементів, які тісно взаємодіють між собою, визначаються залежно від форми страхування, страхового обслуговування, ймовірності настання страхових випадків й необхідності здійснення страхового відшкодування для забезпечення захисту та безпеки у туризмі, що наведено на рис. 1 .

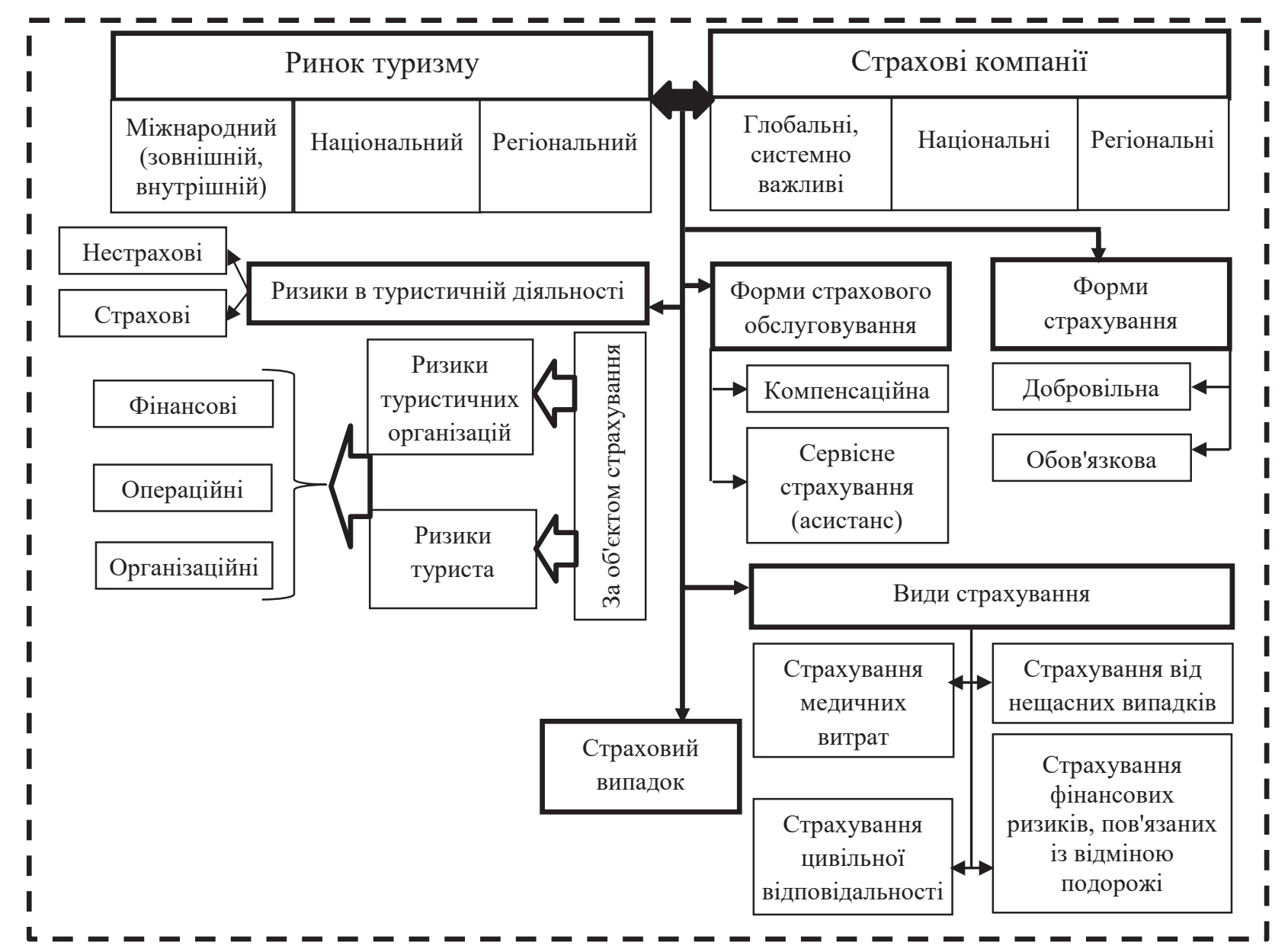

Рис. 1. Елементи системи страхового захисту у туристичній діяльності

Джерело: авторська розробка 
Зовнішній і внутрішній туристичний ринок обслуговують страхові компанії, які функціонують на глобальному, національному й регіональному рівнях, надають послуги із добровільного та обов'язкового страхування. За об'єктом страхування їх доцільно поділити на такі види як:

1) страхування ризиків туристів;

У закордонній практиці, зокрема згідно досліджень та К. Сави та Д-М. Йордан страхування подорожей запропоновано класифікувати таким чином:

- страхування туристів (здоров'я) та їх багажів:

- страхування ризиків для туристичних фірм;

- страхування туристів на виїзд за кордон;

- страхування іноземних туристів;

- страхування цивільної відповідальності (відповідальність, третя особа);

- страхування цивільної відповідальності власників транспортних засобів;

- страхування від непередбачених обставин (на випадок травми, нещасного випадку) та оплата медичних послуг [9, с. 253].

2) страхування ризиків туристичних організацій.

Варто зазначити, що на туристичному ринку страхове обслуговування здійснюється в компенсаційній та сервісній (асистанс) формах.

Компенсаційна форма передбачає, що турист оплачує послуги, а після повернення отримує кошти від страховика.

Сервісне страхування (асистанс) - це надання відповідної підтримки туристу в разі настання страхового випадку та забезпечення зв'язку із відповідним страховиком. Дана форма $є$ переважаючою, використовується в Україні, дозволяе страхувальнику-туристу обирати програму страхування і підходи до здійснення страхового захисту від існуючих ризиків та різновиди страхових полісів. Варто зазначити, що на сьогодні найбільш поширеними $€$ 3 канали реалізації страхових полісів у туризмі:

1) туристичними фірмами (туроператорами чи турагентами шляхом укладення агентських угод);

2) банківськими установами;

3) безпосередньо страховими компаніями.

Сукупність наданих страхових послуг у туризмі - це страховий портфель страховика, який управляється як єдине ціле і спрямовується на досягнення максимальної прибутковості. Згідно досліджень П. Талескі управління страховим портфелем в туристичному бізнесі включає:

- розробку плану страхової діяльності з конкретизацією об'єктів, обсягів страхування, страхового покриття, необхідних умов;

- продаж страхових полісів;

- ознайомлення клієнта із умовами страхової політики;

- ведення страхових полісів впродовж періоду страхування 3 елементами моніторингу та управління усіма питаннями надання страхових послуг, внесення змін за необхідності;
- розгляд претензій з визначенням контактної особи для повідомлення страховику;

- розвиток та підтримку взаємовідносин із страховими брокерами, страховиками та регуляторами претензій на постійній основі;

- проведення страхової експертизи з постійним навчанням шляхом курсів страхування, відвідування майстер-класів і конференцій;

- аналітично-інформаційне забезпечення страхової діяльності з позицій наявності необхідних документів, їх зберігання та управління. Це передбачає ведення обліку аварій, дзвінків, управління та зберігання клієнтських документів, таких як форми звільнення, медичні анкети та реєстраційні форми [10].

Ризики у туристичній діяльності вимагають чіткої ідентифікації, вимірювання, оцінювання та страхування. Страхування визнано у світовій практиці однією із стратегій управління ризиками [11].

Вважаємо, що систематизація ризиків у туристичній діяльності повинна бути здійснена за критеріями їх поділу на ризики туриста та ризики туристичних організацій. Останні пов'язані безпосередньо із діяльністю страхових компаній. Вважаємо, що найбільш характерними видами ризиків у туристичній діяльності є фінансові, організаційні та операційні.

Страховий поліс став обов'язковим атрибутом для туристів під час поїздок за межі країни і $\epsilon$ одним із документів, який необхідний для їх здійснення. Страхування медичних витрат, нещасних випадків, цивільної відповідальності, багажу, фінансових ризиків - це ті види страхування, які можуть надаватись страховими компаніями як окремо, так і комплексно.

Висновки 3 цього дослідження і перспективи подальших розвідок у даному напрямку. Розглянуто суті та значення страхування у туризмі, форми страхування та обслуговування й аргументовано доведено, що це особливий вид цивільноправових відносин, регламентованих договором страхування, пов'язаних із наданням страхового захисту у разі настання страхових випадків в умовах невизначеності та впливу ризиків, які супроводжують діяльність суб'єктів внутрішнього та зовнішнього туризму.

Запропоновано основні елементи системи страхового захисту у туристичній діяльності, які уможливлюють нормативно-правове оформлення обов'язкового, медичного, від нещасного випадку й інших видів страхування туристів, пошук шляхів мінімізації впливу негативних ризиків і загроз та формування особистісної та колективної безпеки туристів, розширення послуг із страхування медичних витрат туристів в умовах пандемії COVID-19, потребу страхування від нещасних випадків.

Систему страхового захисту в туристичній діяльності запропоновано розглядати як сукупність взаємопов'язаних елементів, що тісно вза- 
ємодіють між собою, визначаються залежно від форми страхування й страхового обслуговування, ймовірності настання страхових випадків, необхідності здійснення страхового відшкодування задля забезпечення захисту та безпеки у туризмі.
Подальші дослідження в даному напрямі повинні стосуватися більш поглибленої систематизації страхових ризиків у туристичній діяльності, інструментарію їх ідентифікації, кількісної та якісної оцінки, механізмів їх нейтралізації.

\section{Список використаних джерел:}

1.Diakonidze M. Tourism Insurance Market, Risks and Prospects: The Case Study Journal of Corporate Governance, Insurance, and Risk Management (JCGIRM). 2021. Volume 8. Series 1. Pp. 75-83.

2. Barna M., Semak B. Main trends of marketing innovations development of international tour operating. Baltic Journal of Economic Studies. 2020. Vol. 6. No. 5. Pp. 33-41.

3.Рібун М. В. Особливості ринку страхування у сфері туризму. Науковий вісник НЛТУ Украӥни. 2014. Вип. 24.2. С. 274-281.

4. Абрамітова Д. Р. Розвиток страхування туризму в Україні. Вісник Української академії банківської справи. 2013. № 1. С. 134-138.

5. Козловський Є. В. Загальні питання безпеки та страхування у сфері туризму. Питання культурології. 2013. Вип. 29. С. 67-74.

6. Адамова Р. А. Особенности страхования в туризме. Управление, экономика, политика, социология. 2019. C. 69-73.

7.Вихристенко Б., Опанасюк Н. Правові засади страхування в туризмі. Бюлетень Міністерства юстиціі України. 2012. № 4. С. 10-20.

8. Копилюк О. І., Гузар У. С., Музичка О. М. Системний підхід до формування безпеки страхового бізнесу в Україні. Бізнес Інформ. 2018. № 10. С. 296-301.

9. Sava C., Iordan D-M. How insurance works in tourism. Quaestus Multidisciplinary Research Journal. Pp. 253-268. URL: https://www.quaestus.ro/en/wp-content/uploads/2012/02/sava-iordan.pdf

10.Taleski P. Insurance in tourism industry. URL: https://www.researchgate.net/publication/313881037

11.Ozen E., Grima S. The Turkish Life Insurance Market: An Evaluation of the Current Situation and Future Challenges. In Life Insurance in Europe. 2020. Pp. 45-58.

\section{References:}

1.Diakonidze M. (2020). Tourism Insurance Market, Risks and Prospects: The Case Study Journal of Corporate Governance, Insurance, and Risk Management (JCGIRM), vol. 8, s. 1, pp. 75-83.

2. Barna M., \& Semak B. (2020). Main trends of marketing innovations development of international tour operating. Baltic Journal of Economic Studies, vol. 6, no. 5, pp. 33-41.

3. Ribun M. V. (2014). Osoblyvosti rynku strakhuvannia u sferi turyzmu [Features of the insurance market in the field of tourism]. Naukovyi visnyk NLTU Ukrainy - Scientific Bulletin of NLTU of Ukraine, vol. 24.2, pp. 274-281. (in Ukrainian)

4. Abramitova D. R. (2013). Rozvytok strakhuvannia turyzmu v Ukraini [Development of tourism insurance in Ukraine]. Visnyk Ukrainskoi akademii bankivskoi spravy - Bulletin of the Ukrainian Academy of Banking, no. 1, pp. 134-138. (in Ukrainian)

5. Kozlovsky E. V. (2013). Zahalni pytannia bezpeky ta strakhuvannia u sferi turyzmu [General issues of safety and insurance in the field of tourism]. Pytannia kulturolohii-Questions of culturology, vol. 29, pp. 67-74. (in Ukrainian)

6. Adamova R. A. (2019). Osobennosti strahovanija v turizme [Features of insurance in tourism]. Upravlenie, ekonomika, politika, sociologija-Management, economics, politics, sociology, pp. 69-73. (in Russian)

7. Vykhristenko B., \& Opanasyuk N. (2012). Pravovi zasady strakhuvannia v turyzmi [Legal bases of insurance in tourism]. Biuleten Ministerstva yustytsii Ukrainy - Bulletin of the Ministry of Justice of Ukraine, no. 4, pp. 10-20. (in Ukrainian)

8. Kopylyuk O. I, \& Guzar U. E., \& Muzychka O. M. (2018). Systemnyi pidkhid do formuvannia bezpeky strakhovoho biznesu v Ukraini [System approach to the formation of insurance business security in Ukraine]. Business Inform - Biznes Inform, no. 10, pp. 296-301. (in Ukrainian)

9. Sava C., \& Iordan D-M. (2012). How insurance works in tourism. Quaestus Multidisciplinary Research Journal, pp. 253-268. URL: https://www.quaestus.ro/en/wp-content/uploads/2012/02/sava-iordan.pdf

10.Taleski P. (2018). Insurance in tourism industry. URL: https://www.researchgate.net/publication/313881037

11. Ozen E., Grima S. (2020). The Turkish Life Insurance Market: An Evaluation of the Current Situation and Future Challenges. In Life Insurance in Europe, pp. 45-58. 